\title{
Florivory by a Cuban Green Anole, Anolis porcatus (Squamata: Dactyloidae)
}

Luis F. de Armas

P.O. Box 4327, San Antonio de los Baños, Artemisa 38100, Cuba (luisdearmas1945@gmail.com)

Photographs by the author.

$\Lambda$ noles are known to consume a wide variety of inverAtebrates, occasional small vertebrates, and the diet of some species also includes nectar, pollen, flowers, and fruit (Henderson and Powell, 2009 and references therein). The Cuban Green Anole (Anolis porcatus Gray 1840; Fig. 1) is widely distributed across much of the Cuban Archipelago and is abundant in towns and other anthropogenic areas (Rodríguez-Schettino 1999). It is an opportunistic and generalist feeder (e.g., Henderson and Powell 2009; Armas and Iturriaga 2019), but only one report by Townsend (2003) documented the consumption of a single flower of the exotic Areca Palm (Dypsis lutescens) in Florida, USA.

At 1548 h on 17 March, 2019, in the backyard of an urban home in San Antonio de los Baños (22053'36.49”N,
82030'35.21”W, 75 m a.s.l.), Artemisa Province, Cuba, I observed an adult female $A$. porcatus eating a recently opened orchid flower of Lueddemann's Cattleya (Cattleya lueddemanniana; Fig. 2). During February and the first week of March, more than twenty orchids were open each day, but on 17 March only a single flower was blooming. Although I did not have a camera at hand, several minutes later this individual was on the same flower eating ants (Fig. 1). Two days later, its bites on the orchid sepal remained evident (Fig. 2). I observed no additional florivory by any lizard during the following week.

Flowers have fleshy tissues that provide anoles with effortless access to energy and nutrients (e.g., Schall and Ressel 1991). Also, as most flowers are seasonal, lizards oppor-

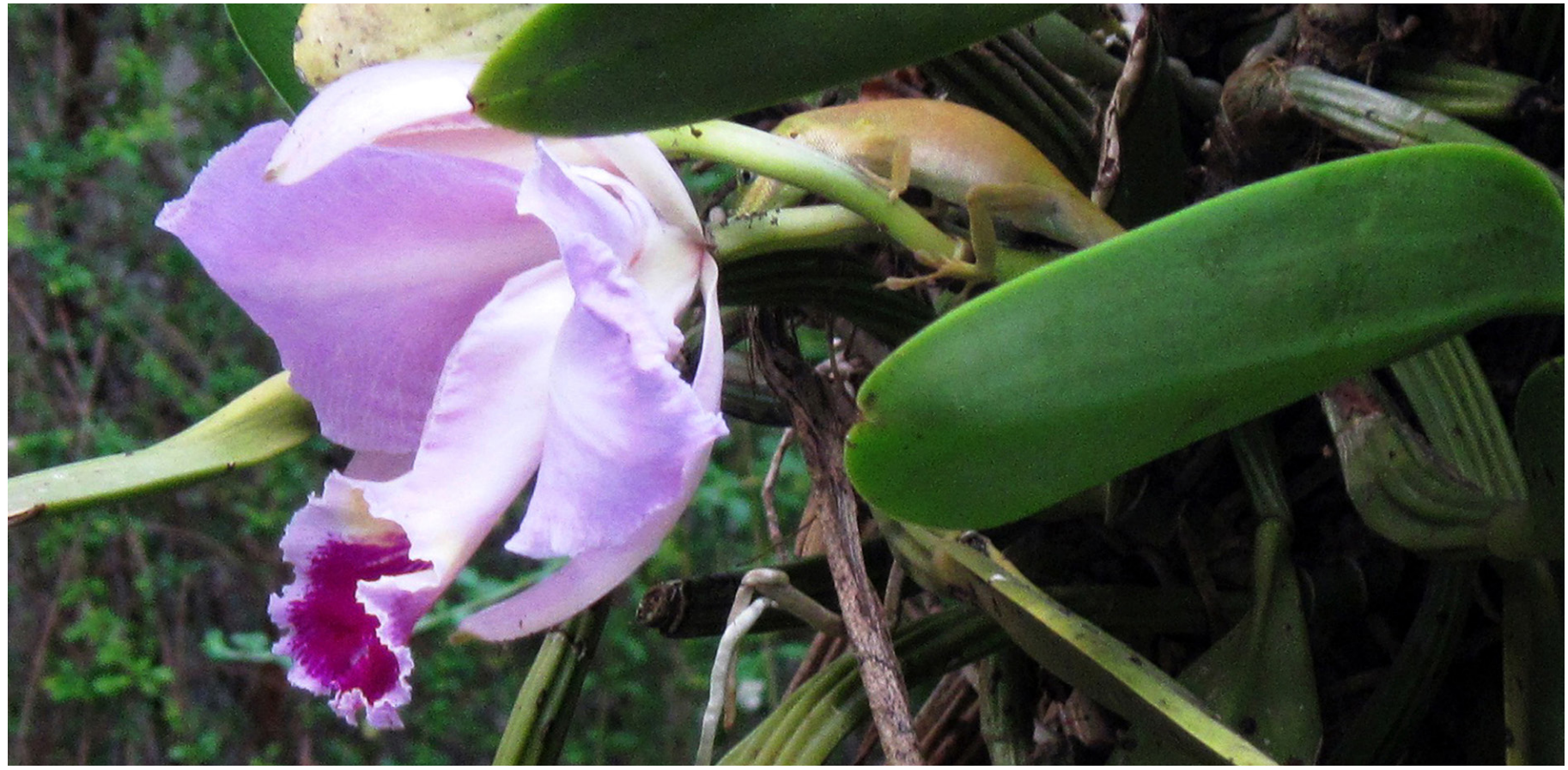

Fig. 1. A female Cuban Green Anole (Anolis porcatus) feeding on ants on the flower of an orchid, Lueddemann's Cattleya (Cattleya lueddemanniana), in the backyard of an urban home in San Antonio de los Baños, Artemisa Province, Cuba. This is the same female that consumed parts of this flower ten minutes earlier. 

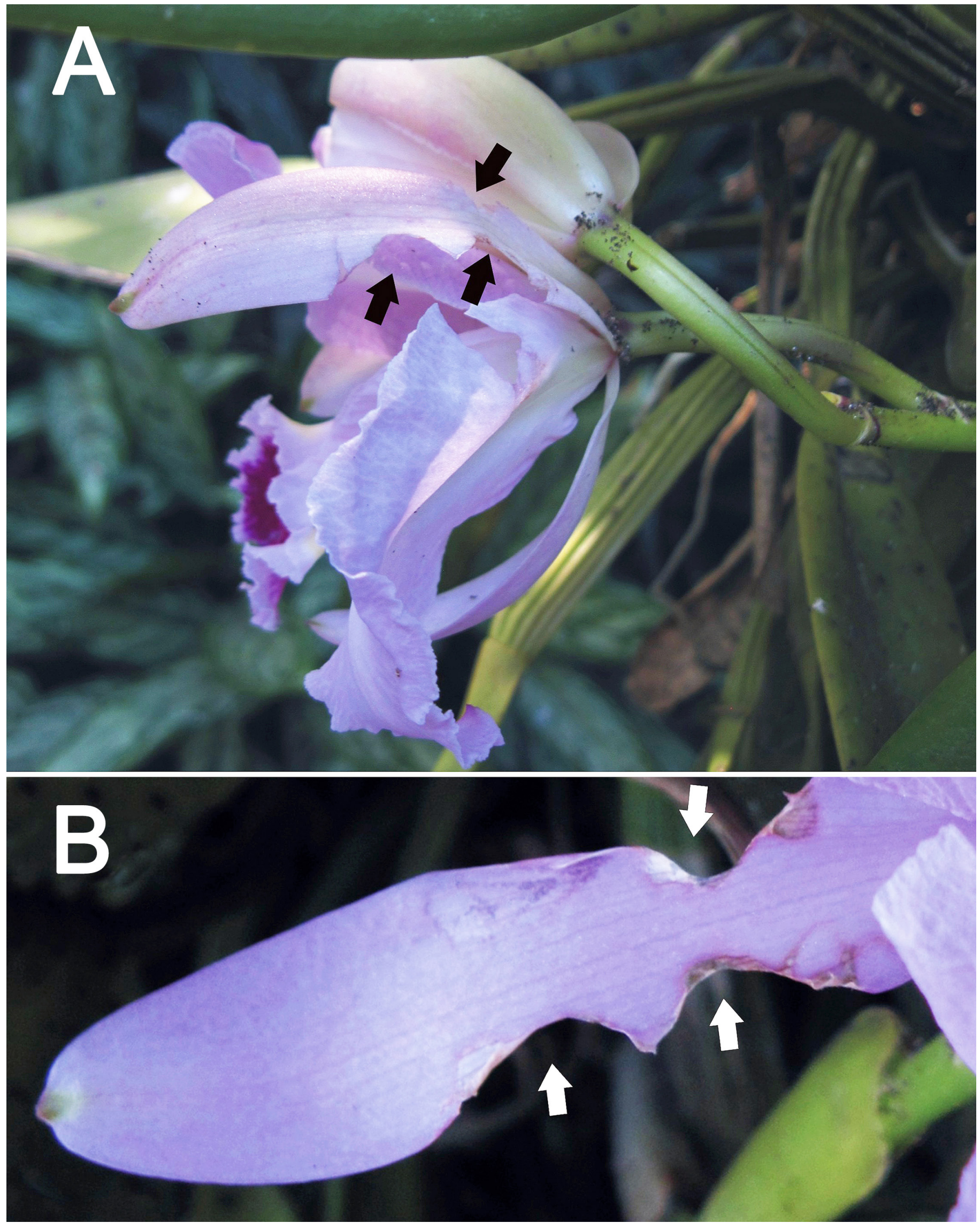

Fig. 2. Flower of an orchid, Lueddemann's Cattleya (Cattleya lueddemanniana) showing the bite marks (arrows) where a female Cuban Green Anole (Anolis porcatus) had fed on a sepal. The lower photograph (B) was taken two days after the upper image (A). 
tunistically utilize them when available (Pough et al. 2016). Although fruits, nectar, and pollen have been recorded as food items for Cuban Green Anoles (see Armas and Iturriaga 2019), this is the first report of $A$. porcatus or any other Cuban anole feeding on an orchid flower.

\section{Acknowledgements}

Manuel Iturriaga Monsisbay, Instituto de Ecología y Sistemática, La Habana, provided literature. In addition, he and Sonia Seuc, Mego Networks S.A.C. in Lima, Peru, reviewed an earlier draft of this manuscript.

\section{Literature Cited}

Armas, L.F. de and M. Iturriaga. 2019. The Cuban Green Anole, Anolis porcatus (Squamata: Dactyloidae): Catering is the best. Reptiles \& Amphibians 26: 35-38.

Henderson, R.W. and R. Powell. 2009. Natural History of West Indian Reptiles and Amphibians. University Press of Florida, Gainesville, Florida.

Rodriguez-Schettino, L. 1999. Systematic accounts of the species, pp. 104-380. In: L. Rodríguez-Schettino (ed.), The Iguanid Lizards of Cuba. University Press of Florida, Gainesville, Florida.

Pough, F.H., R.M. Andrews, M.L. Crump, A.H. Savitzky, K.D. Wells, and M.C. Bradley. 2016. Herpetology. 4th ed. Sinauer Associates, Sunderland, Massachusetts.

Schall, J.J. and S. Resell. 1991. Toxic plant compounds and the diet of the predominantly herbivorous whiptail lizard, Cnemidophorus arubensis. Copeia 1991: 111-119.

Townsend, J.H. 2003. Anolis porcatus (Cuban Green Anole). Nectivory. Herpetological Review 34: 141-142. 